\title{
EFFECT OF IRRIGATION WATER SALINITY LEVELS AND DIFFERENT ORGANIC MANURES COMBINED WITH BIO- FERTILIZERS ON GROWTH OF CONOCARPUS ERECTUS L. TRANSPLANTS
}

\author{
Hanan E. Ibrahem \\ Ornamental Plants and Landscape Gardening Res. Dept., Hort. Res. Inst., ARC, Giza, Egypt.
}

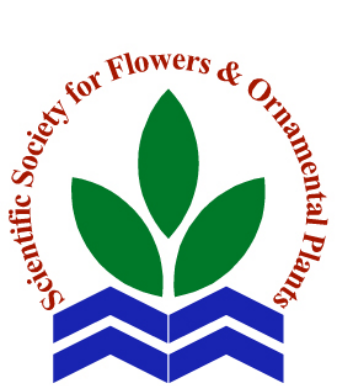

Scientific J. Flowers \& Ornamental Plants, 3(2):135-146 (2016).

Received: $1 / 6 / 2016$

Revised by: Prof. Dr. E.S. Nofal, Kafr El-Sheikh Univ.

ABSTRACT: A pot experiment was conducted in the Orman Botanical Garden, Giza, Egypt, during two successive seasons of 2014 and 2015 to study the effect of different saline water levels $(970,5000$, 8000 and $12000 \mathrm{ppm}$ ) and organic manure (cattle manure and chicken manure) combined with bio-fertilizers on Conocarpus erectus L. transplants productivity. The results indicated that there were decreases due to the effect of irrigation water levels salinity and organic manures in plant height $(\mathrm{cm})$, root length $(\mathrm{cm})$, stem diameter $(\mathrm{cm})$, No. of leaves, fresh and dry weight of roots $(\mathrm{g}) /$ plant, fresh and dry weights of vegetative parts of Conocarpus erectus transplants with increasing water salinity. On the other hand, chlorophyll a, b and carotenoids content in the leaves decreased with increasing irrigation water levels with or without organic manures. The $\mathrm{N}, \mathrm{P}$ and $\mathrm{K}$ percentages in the leaves were increased with decreasing irrigation water salinity and organic manures, while the $\mathrm{Na}^{+}, \mathrm{Cl}^{-}$and proline concentration in the leaves increased with increasing irrigation water salinity and organic Prof. Dr. Boshra A. El-Sayed, manures combined with bio-fertilizers.

Hort. Res. Inst., ARC.

Key words: irrigation water salinity, organic manures, bio-fertilizers, Conocarpus erectus.

\section{INTRODUCTION}

Demands of water are continually increasing especially for agriculture production, where water consumption is more than any other human activity sectors. Meantime, great amounts of saline water are normally available through seawater or produced from agricultural drainage or industrial production, of Conocarpus erectus (El-Mahrouk et al., 2010). Maksimovic and Ilin (2012) reported that irrigation water salinity affects nutrient availability to plants in many ways. It modifies binding, retention and transformation of nutrients in soil and affects the uptake and/or absorption of nutrients by the root system of Conocarpus erectus. El-Kady and Borham (2013) showed that the accumulation of $\mathrm{Na}^{+}$and $\mathrm{Cl}^{-}$in soil solution may be due to their increased levels by increasing irrigation water salinity which, consequently increase their contents in plant leaves of Conocarpus erectus. Muhammad et al. (2014) indicated that increasing of water salinity level led to decrease fresh weight of roots, fresh weight of leaves, dry and fresh weights of stem. Hasan (2010) studied the response of Conocarpus plant to saline irrigation water at salinity levels of 1500 , 2500,3500 and $4500 \mathrm{ppm}$ and found that by increasing salinity level the relative growth of the plant was significantly decreased.

Certain strains of microbes are referred to as plant growth-promoting rhizobacteria (PGPR), which can be used as inoculants bio-fertilizers (Kennedy et al., 2004). 
Branzini et al. (2009) showed that at the end of the incubation period, the total activity of microorganisms was significantly increased by the application of organic amendments and a negative relationship was observed between salinity and $\mathrm{CO}_{2}$.

Organic application to soil is important to increase $\mathrm{N}$ and $\mathrm{P}$ contents in the soil and could accelerate the decomposition of the organic matter in the soil and increase crop production, (Cleveland and Townsend, 2006). Chicken manure is preferred amongst other animal wastes because of its high concentration of macro-nutrients (Duncan, 2005). Addition of chicken manure increased available $\mathrm{P}$ with application rate for all soil types as well as, the increase of $\mathrm{P}$ and $\mathrm{N}$ concentration due to chicken manure addition was significant. Oagile and Namasiku (2010) and Muhammad and Khattak (2009) reported that organic manures may increase soil fertility and thus the crop production potential possibly by changes in soil physical and chemical properties including nutrient bio-availability, soil structure, water holding capacity, soil $\mathrm{pH}$ and activity of microbial community. Sarwar et al. (2010) found that the combined application of both organic and inorganic fertilizers improved chemical properties of soil and enriched the fertility status of soil. Khaled et al. (2011) indicated that the application of organic farm increases microbial activity in the soil, which may increase the organic matter contents in soil compared with control. Also, the application of organic farm fertilizer decreases soil $\mathrm{pH}$, soil salinity and because the organic farm could improve the soil physical properties i.e. (increase soil porosity, aggregation practical size and activity of microorganism).

Bio-fertilizers are essential component of organic farming. The preparations containing live or latent cells of efficient strains of nitrogen fixing, phosphate solubilizing or cellulolytic micro-organisms used for application to seed, soil or composting. The objective of increasing number of such micro-organisms and accelerate those microbial processes which augment the availability of nutrients that can be easily assimilated by plants. Biofertilizers play a very significant role in improving soil fertility by fixing atmospheric nitrogen, both, in association with plant roots and without it, solubilize insoluble soil phosphates and produce plant growth substances in the soil. They are in fact being promoted to harvest the naturally available, biological system of nutrient mobilization (Venkatashwarlu, 2008).

This investigation was carried out to study the effect of irrigation water salinity and organic manures (5 g/pot) combined with bio-fertilizers $(5 \mathrm{~g} /$ pot) on Conocarpus erectus productivity, quality and chemical compositions.

\section{MATERIALS AND METHODS}

A pot experiment was conducted in the Orman Botanical Garden, Giza, Egypt, during two successive summer seasons of 2014 and 2015 to study the effect of saline water levels (970, 5000, 8000 and 12000 ppm) and using organic manure (Cattle and Chicken manures) combined with biofertilizers (Rhizobcterein $s p$ strain) nitrogen fixation and Bacillus megatherium (dissolving phosphate) on growth of Conocarpus erectus L. transplants. Planting of Conocarpus erectus L. transplants was in February to October 2014 and 2015 seasons. The transplant was $35 \mathrm{~cm}$ length with 3-5 leaves. The daily temperature during the both seasons ranged from 20 to $36^{\circ} \mathrm{C}$.

Before planting was undertaken a soil sample of the experimental soil was airdried, ground, good mixed, sieved through a $2 \mathrm{~mm}$ sieve, kept and analyzed for some physical and chemical properties and its content of available macro and micronutrients according to the methods described by Page et al. (1982) and Kim (1996). Physical and chemical properties of the studied soil are presented in Table (1). 
Table 1. Physical and chemical properties of the soil of the experiment.

\begin{tabular}{|c|c|c|c|c|c|c|c|c|}
\hline $\begin{array}{c}\text { Coarse sanc } \\
\text { (\%) } \\
4.30\end{array}$ & & & $\begin{array}{c}\text { Silt } \\
(\%) \\
33.82\end{array}$ & $\begin{array}{c}\text { Clay } \\
(\%) \\
44.28\end{array}$ & $\begin{array}{l}\text { Texture } \\
\text { Clayey }\end{array}$ & & & $\begin{array}{c}\mathrm{CaCO}_{3} \\
(\%) \\
2.67\end{array}$ \\
\hline \multirow{2}{*}{ pH (1:2:5) } & \multirow{2}{*}{$\begin{array}{c}\text { EC } \\
(\mathrm{dS} / \mathrm{m})\end{array}$} & \multicolumn{3}{|c|}{ Cations (meq/l) } & & \multicolumn{3}{|c|}{ Anions (meq/l) } \\
\hline & & $\mathrm{Ca}^{++}$ & $\mathbf{M g}^{++}$ & $\mathrm{Na}^{+}$ & $\mathbf{K}^{+}$ & $\mathrm{HCO}_{3}^{-}$ & $\mathrm{Cl}^{-}$ & $\mathrm{SO}_{4}^{--}$ \\
\hline 8.02 & 2.14 & 5.50 & 3.23 & 11.83 & 0.84 & 2.28 & 6.88 & 12.24 \\
\hline \multicolumn{9}{|c|}{ Available of Macronutrients (mg/kg) } \\
\hline \multicolumn{3}{|c|}{$\mathbf{N}$} & \multicolumn{3}{|c|}{3.76} & \multicolumn{3}{|c|}{$\mathbf{K}$} \\
\hline
\end{tabular}

The transplants were home planted in plastic pots of $40 \mathrm{~cm}$ diameter. The experiment was conducted in a complete randomized block design with 3 replicates and each replicates contained five plants.

All experimental pots were divided into two groups the first group was treated with chicken manure mixed with clay soil by $(1: 2$ $\mathrm{v} / \mathrm{v})$ and second group was treated with cattle manure mixed with clay soil by $(1: 2 \mathrm{v} / \mathrm{v})$. The organic manures (chicken manure and cattle manure) were applied mixed with soil 12 days before planting.

Physical and chemical characteristics of the organic amendments used in the study are shown in Table (2).

Bio-fertilizers of Rhizobacterein $s p$. strain for nitrogen fixation and phosphorein of Bacillus megatherium dissolving phosphate were obtained from Unit Department of Microbiology Soils, Water and Environment Res. Inst., Agric. Res. Center, Giza, Egypt. The bio-fertilizers were applied at $5 \mathrm{~g} /$ pot in the soil before irrigation water every month of planting.

The transplants were irrigated with saline water at levels of 970, 5000, 8000 and 12000 ppm, respectively. Plants were irrigated after two weeks from transplanting with $500 \mathrm{ml}$ of saline water levels per pot, whereas the control was irrigated with Nile water $(970 \mathrm{ppm})$.

Water analysis (Table 3) was carried out during the two growing seasons according to the methods described by Cottenie et al. (1982).

Table 2. Physical and chemical properties of the organic manure (cattel and chicken manures which were used in the study.

\begin{tabular}{lccccccc}
\hline \multirow{2}{*}{$\begin{array}{l}\text { Organic } \\
\text { amendments }\end{array}$} & $\mathbf{p H}$ & $\begin{array}{c}\mathbf{E C} \\
\left.\mathbf{d S m}^{-\mathbf{1}}\right)\end{array}$ & $\begin{array}{c}\text { Bulk } \\
\text { density } \\
\left(\mathbf{m g} / \mathbf{m}^{\mathbf{3}}\right)\end{array}$ & $\begin{array}{c}\text { Organic } \\
\mathbf{C}(\%)\end{array}$ & \multicolumn{3}{c}{$\begin{array}{c}\text { Available } \\
\text { macronutrients (\%) }\end{array}$} \\
\hline Cattle manure & 7.58 & 2.79 & 0.82 & 30.14 & 2.24 & 0.28 & 2.36 \\
Chicken manure & 7.62 & 2.94 & 0.66 & 27.16 & 2.10 & 0.21 & 2.28 \\
\hline
\end{tabular}

Table 3. Chemical properties of the irrigation water which were used.

\begin{tabular}{cccccc}
\hline \multirow{2}{*}{$\begin{array}{c}\text { Irrigation water } \\
\text { Salinity } \\
\left.\mathbf{( d S m}^{-1}\right)\end{array}$} & $\mathbf{p H}$ & \multicolumn{4}{c}{ Available macronutrients (mg/kg) } \\
\cline { 3 - 6 } & & NO3- $\mathbf{N}$ & $\mathbf{N H 4}-\mathbf{N}$ & $\mathbf{P}$ & $\mathbf{K}$ \\
\hline 0.97 & 7.78 & 12.84 & 9.25 & 4.25 & 7.95 \\
5 & 7.94 & 10.69 & 6.55 & 3.58 & 7.14 \\
8 & 8.03 & 7.99 & 5.41 & 3.10 & 6.38 \\
12 & 8.05 & 6.21 & 4.00 & 2.94 & 5.94 \\
\hline
\end{tabular}


The data recorded at the end of experiments on October $10^{\text {th }}$ for both seasons:

- Plant height (cm)

- Root length (cm)

- Stem diameter $(\mathrm{cm})$

- No. of leaves/plant

- Fresh weight of roots (g)

- Dry weight of roots $(\mathrm{g})$

- Fresh weight of vegetative parts (g)

- Dry weight of vegetative parts (g)

Macro content $(\mathrm{N}, \mathrm{P}$ and $\mathrm{K})$ in plant leaves were determined according to Ryan et al. (1996). Chlorophyll (a, b) and carotenoids were estimated in fresh leaves as described by Witham et al. (1971). Proline content in the leaves was estimated according to the method described by Bates et al. (1973).

The obtained results were subjected to statistical analysis according to Snedecor and Cochran (1990). The least significant differences (LSD at 0.05) was used to compare the treatment means.

\section{RESULTS AND DISCUSSION}

Effect of irrigation water salinity and organic manures on Conocarpus erectus vegetative parameters

\section{Plant height}

Data presented in Table (4) show that the irrigation water salinity levels and applied organic manure combined with biofertilization significantly increased plant height of Conocarpus erectus L. transplants especially with decreasing of irrigation water salinity. The interaction between saline water levels and organic manure combined with bio-fertilizers caused significant decrease in plant height with increasing water salinity. These results are in agreement with those of Muhammad et al. (2014) who suggested that plant height of Conocarpus erectus was decreased with increasing irrigation water salinity. The maximum decrease of plant height was $42.16 \mathrm{~cm}$ in the first season and $36.00 \mathrm{~cm}$ in the second one recorded with water level salinity of $12000 \mathrm{ppm}$ and without organic manures. Corresponding relative decrease the mean values of plant height $(\mathrm{cm})$ was $6.53 \%$ for irrigation water salinity of $5 \mathrm{dSm}^{-1} ; 19.60 \%$ for irrigation water salinity of $8 \mathrm{dSm}^{-1}$ and $26.89 \%$ for irrigation water salinity of $12 \mathrm{dSm}^{-1}$ respectively, in the first season and 5.97\% for irrigation water salinity of $5000 \mathrm{ppm}$; $19.57 \%$ for irrigation water salinity of 8000 ppm and $31.99 \%$ for irrigation water salinity of $12000 \mathrm{ppm}$ respectively, in second one compared with control irrigation water of $970 \mathrm{ppm}$ and organic manures combined with bio-fertilizers. The decrease in plant height due to high salinity levels can be elucidated by the reduction in osmotic potential and decrease of nutrients. Muhammad et al. (2014) reported that the water salinity irrigation decreased plant height due to the closure of stomata and inactivation of enzymatic system occurred owing to the decrease in internal and external osmotic potential. The metabolic pathway is changed by accumulation of salts in cell wall; elasticity of cell well decreased and ultimately reduced the plant height (Hameed et al., 2010).

\section{Root length}

The effect of irrigation water salinity levels with or without cattle and chicken manures combined with bio-fertilizers on root length $(\mathrm{cm})$ of Conocarpus erectus transplants is presented in Table (4). Generally the root length (cm) was significantly inhibited by increasing water salinity levels with or without organic manures.

For the interaction between irrigation water salinity levels and organic manures combined with bio-fertilizers caused significant increment in root length with decreased irrigation water level with organic manures than without organic manures. 
Table 4. Effect of organic amendments and saline water levels on growth parameters of Conocarpus erictus L. transplants in two seasons.

\begin{tabular}{|c|c|c|c|c|c|c|c|c|c|}
\hline \multirow{2}{*}{$\begin{array}{c}\text { Organic } \\
\text { amendments } \\
\text { (A) }\end{array}$} & \multirow{2}{*}{$\begin{array}{c}\text { EC } \\
\text { ( ppm)of } \\
\text { irrigation } \\
\text { water } \\
\text { (B) }\end{array}$} & \multicolumn{4}{|c|}{ First season } & \multicolumn{4}{|c|}{ Second seasons } \\
\hline & & $\begin{array}{c}\text { Plant } \\
\text { height } \\
\text { (cm) }\end{array}$ & $\begin{array}{c}\text { Root } \\
\text { length } \\
(\mathrm{cm})\end{array}$ & $\begin{array}{c}\text { Stem } \\
\text { diameter } \\
(\mathrm{cm}) \\
\end{array}$ & $\begin{array}{l}\text { No. of } \\
\text { leaves }\end{array}$ & $\begin{array}{c}\text { Plant } \\
\text { height } \\
\text { (cm) }\end{array}$ & $\begin{array}{c}\text { Root } \\
\text { length } \\
\text { (cm) }\end{array}$ & $\begin{array}{c}\text { Stem } \\
\text { diameter } \\
(\mathrm{cm})\end{array}$ & $\begin{array}{l}\text { No. of } \\
\text { leaves }\end{array}$ \\
\hline Control & \multirow{4}{*}{970} & 54.30 & 40.33 & 1.20 & 157 & 58.00 & 52.48 & 1.32 & 164 \\
\hline FYM + bio & & 62.00 & 50.00 & 1.27 & 178 & 60.00 & 56.94 & 1.38 & 169 \\
\hline Ch. $\mathbf{M}+$ bio & & 56.33 & 48.33 & 1.22 & 163 & 66.00 & 54.00 & 1.34 & 166 \\
\hline Mean ( B1) & & 57.54 & 46.22 & 1.23 & 166 & 61.33 & 54.47 & 1.35 & 166.33 \\
\hline Control & \multirow{4}{*}{5000} & 53.24 & 37.67 & 1.13 & 149 & 54.00 & 49.42 & 1.20 & 158 \\
\hline FYM + bio & & 58.45 & 48.00 & 1.22 & 162 & 63.00 & 51.61 & 1.27 & 165 \\
\hline Ch. $\mathbf{M}+$ bio & & 49.66 & 44.36 & 1.14 & 157 & 56.00 & 50.32 & 1.25 & 162 \\
\hline Mean (B2) & & 53.78 & 43.34 & 1.16 & 156 & 57.67 & 50.45 & 1.24 & 161.67 \\
\hline Control & \multirow{4}{*}{8000} & 47.33 & 36.22 & 1.05 & 137 & 46.00 & 43.55 & 1.19 & 149 \\
\hline FYM + bio & & 49.67 & 44.77 & 1.13 & 143 & 52.00 & 48.32 & 1.23 & 155 \\
\hline Ch. $\mathbf{M}+$ bio & & 41.77 & 40.12 & 1.08 & 137 & 50.00 & 44.32 & 1.20 & 151 \\
\hline Mean (B3) & & 46.26 & 40.37 & 1.09 & 139 & 49.33 & 45.40 & 1.21 & 151.67 \\
\hline Control & \multirow{3}{*}{12000} & 42.16 & 33.65 & 1.10 & 116 & 36.00 & 41.02 & 1.16 & 147 \\
\hline FYM + bio & & 43.77 & 38.21 & 1.06 & 128 & 48.12 & 43.98 & 1.22 & 153 \\
\hline Ch. M+ bio & & 40.28 & 33.11 & 1.03 & 122 & 41.00 & 42.10 & 1.18 & 142 \\
\hline & 42.07 & 34.99 & 1.06 & 122 & 41.71 & 42.37 & 1.19 & 147.33 \\
\hline \multicolumn{2}{|c|}{ (A1) Mean of control } & 49.26 & 36.97 & 1.12 & 139.75 & 48.50 & 46.62 & 1.22 & 154.50 \\
\hline \multicolumn{2}{|c|}{ (A2) Mean FYM } & 53.47 & 45.25 & 1.17 & 152.75 & 55.78 & 50.21 & 1.28 & 160.50 \\
\hline \multicolumn{2}{|c|}{ (A3) Mean Ch. M } & 47.01 & 41.48 & 1.12 & 144.75 & 53.25 & 47.69 & 1.24 & 155.25 \\
\hline \multicolumn{2}{|c|}{ LSD 5\% Water salinity } & 2.35 & 2.66 & 0.050 & 0.77 & 3.20 & 2.41 & 0.087 & 1.47 \\
\hline \multicolumn{2}{|c|}{ LSD 5\% Organic } & 2.04 & 2.30 & 0.042 & 0.67 & 2.77 & 2.10 & NS & 1.27 \\
\hline \multicolumn{2}{|l|}{ Interaction } & 2.53 & 3.44 & 0.10 & 1.58 & 7.51 & 3.05 & NS & 5.17 \\
\hline
\end{tabular}

A1: Mean control without amendments, A2: Mean of FYM, A3: Mean of Ch. M, B1: irrigation water salinity 970 ppm, B2: irrigation water salinity 5000 ppm, B3: irrigation water salinity 8000 ppm and B4: irrigation water salinity 12000 ppm.

On the other hand, increasing salinity water levels from 8000 to $12000 \mathrm{ppm}$ decreased the mean root length $(\mathrm{cm})$ from $40.37 \mathrm{~cm}$ to $34.99 \mathrm{~cm}$ in the first season and from 45.40 to $42.37 \mathrm{~cm}$ in the second one. The relative decreases in mean values root length were $6.23,12.66$ and $24.30 \%$ for irrigation water levels of $5000 ; 8000$ and $12000 \mathrm{ppm}$ respectively, in the first season and $7.38,16.65$ and $22.21 \%$ for irrigation water salinity of 5000, 8000 and 12000 ppm with or without organic manures respectively in the second one, compared with control irrigated with fresh water of $970 \mathrm{ppm}$. Generally there was a inhibitory effect on root length of Conocarpus erectus L. by using salinity water and this may be attributed to high osmotic pressure in soil solution which restricted the absorption of water by plant roots. Abd El-Aziz et al. (2011) found that various compost treatments and different water salinity levels significantly decreased root length with increasing water salinity.

\section{Stem diameter}

Data presented in Table (4) show that the stem diameter $(\mathrm{cm})$ was significantly increased with decreased irrigation water levels throughout the two growing seasons. The application of organic manures combined with bio-fertilizers had a significant effect on stem diameter $(\mathrm{cm})$ in the first season, while a non significant effect in second one. The interaction between irrigation water salinity and organic manures combined with bio-fertilization significantly increased stem diameter (cm) with 
decreasing irrigation water salinity. The highest values of stem diameter $1.27 \mathrm{~cm}$ and $1.38 \mathrm{~cm}$ were resulted from the cattle manure and irrigation water of $(970 \mathrm{ppm})$ in the first and second seasons, respectively. The relative decreases of mean values of stem diameter $(\mathrm{cm})$ were $5.69,11.38$ and $13.82 \%$ in the first season and 8.15, 10.37 and $11.85 \%$ in the second one compared with control. Irrigation water salinity conditions led to reduce the ability of plants to absorb water causing rapid reductions in stem diameter $(\mathrm{cm})$. These results are in agreement with those of Abd El-Aziz et al. (2011) who showed that under the irrigation water salinity at the different levels, it is clear that under increasing salinity levels significantly decreased stem diameter. It can be mentioned that the depression in stem by salt stress may be attributed to the plant withdraw from the soil, even in moist soil. Muhammad et al. (2014) revealed that with increasing salinity, stem diameter was reduced. The stem diameter decreased due to the reduction in turgor potential and division of cells.

\section{Number of leaves per plant}

Data presented in Table (4) show that irrigation water salinity levels and organic manures (cattle manure and chicken manure combined with bio-fertilization) had significant effects on number of leaves per plant of Conocarpus erectus. The interaction between irrigation water at different salinity levels and organic manures caused significant increase in number of Conocarpus erectus leaves with decreased water salinity. The least mean values of No. of leaves per plant was obtained from plants irrigated by $12000 \mathrm{ppm}$ in the first season and 147.33 in second one for water salinity at level of $12000 \mathrm{ppm}$. The relative decreases of mean values of No. leaves was 6.02, 16.27 and $26.51 \%$ in the first season and $2.80,8.81$ and $11.42 \%$ in the second one for plants treated with irrigation water levels of 5000, 8000 and 12000 ppm compared with control (970 ppm) with or without organic manures. These results are in agreement with the findings of Loutfy and Ibrahim (2005) who reported that the high salt concentration in irrigation water levels reduced No. leaves of Conocarpus erectus compared with those in low salt concentration. Muhammad et al. (2014) suggested that the No. leaves per plant of Conocarpus erectus decreased by the increased saline stress.

Generally it is concluded that the use of organic manure (cattle) combined with biofertilizers led to the best morphological characters of Conocarpus erectus under used irrigation water conditions compared with applied chicken manure combined with biofertilizers.

\section{Fresh and dry weights of roots}

Data presented in Table (5) show that the weight of the fresh and dry roots of Conocarpus erectus were decreased by increasing salinity water alone or treated with organic manures combined with biofertilizers. The maximum increase of mean value of roots fresh and dry weights was 63.91 and $36.07 \mathrm{~g}$ in the first season and 66.46 and $41.48 \mathrm{~g}$ in the second one, respectively obtained from control as compared with other treatments. The effect of irrigation water salinity, organic manures and their interaction on roots fresh weight significantly increased with decreased irrigation water salinity in both seasons, while roots dry weight had a non significant effect by irrigation water salinity levels in the first season. Also, organic manures combined with bio-fertilizers and the interaction between irrigation water salinity and organic manures significantly affected fresh and dry weight of roots. The relative decrease of mean values weight of fresh and dry roots were 15.85 and $6.60 \%$ in the first season and 11.44 and $7.30 \%$ in the second one as affected by irrigation water salinity + organic manures compared with control + organic manures. Mohammad et al. (2015) evaluated the effect of saline irrigation water at five levels of $0,5,10,15$ and 20 grams per liter of sodium chloride salt on the roots wet and dry weight of Conocarpus plant. The results showed that the fresh and dry roots 
Table 5. Effect of organic amendments and saline water levels on fresh and dry weights of Conocarpus erictus $\mathrm{L}$. roots and vegetative parts in two seasons.

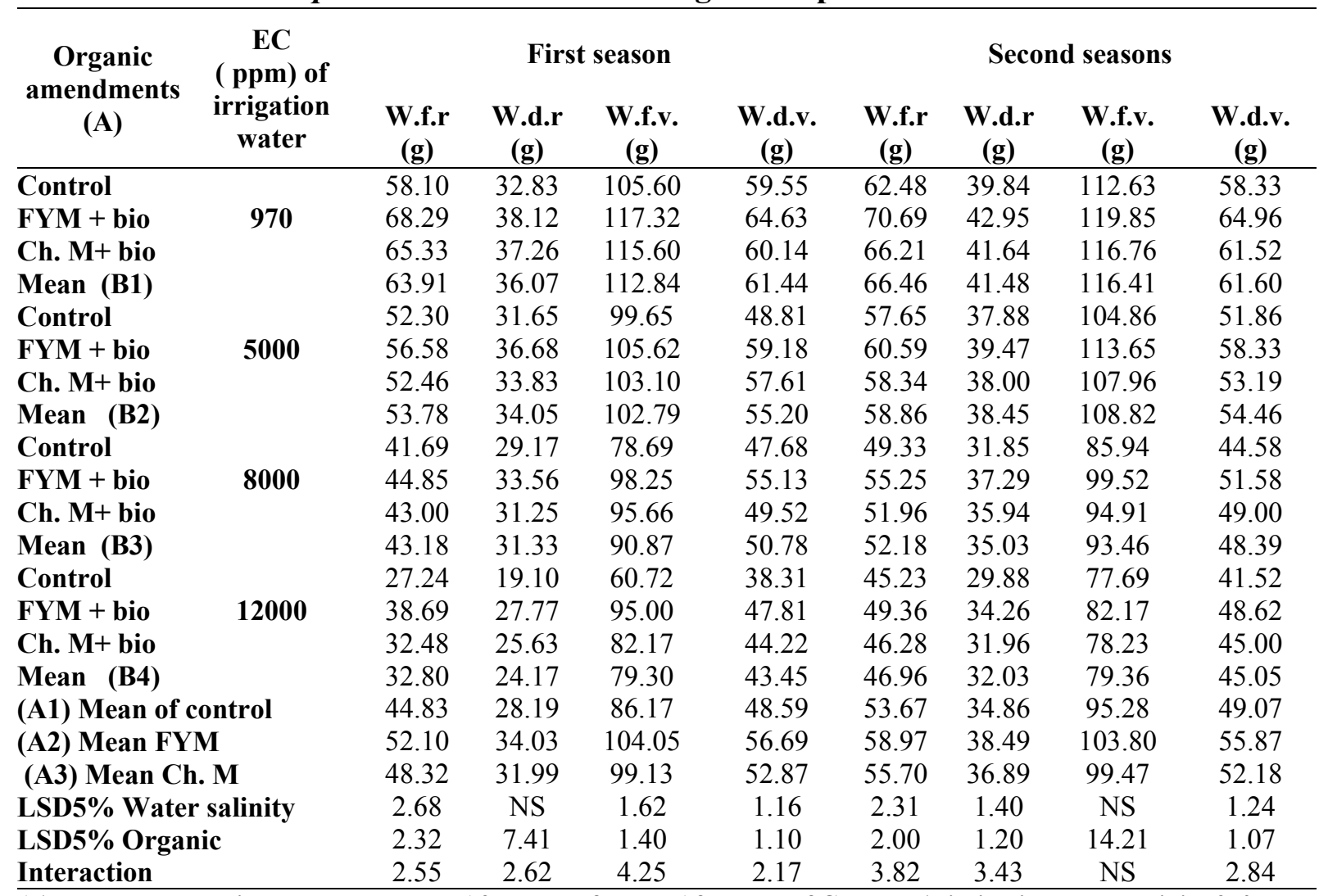

A1: Mean control without amendments, A2: Mean of FYM, A3: Mean of Ch. M, B1: irrigation water salinity $970 \mathrm{ppm}$, B2: irrigation water salinity 5000 ppm, B3: irrigation water salinity 8000 ppm and B4: irrigation water salinity 12000 ppm. W.f.r $=$ root fresh weight, W.d.r $=$ root dry weight, W.f.v. $=$ fresh weight of vegetative parts and W.d.v. $=$ dry weight of vegetative parts.

weight was decreased by increasing the different salinity levels and organic manures.

\section{Fresh and dry weights of vegetative parts}

Data presented in Table (5) show that, applying organic manures combined with bio-fertilizers and saline irrigation water had significant effects in the first season on fresh and dry weight of vegetative parts, while the irrigation water salinity only had no significant effects in the second one for fresh weight of vegetative parts. Concerning the interaction between water salinity and organic manures on fresh and dry weights of vegetative parts they were significant in the first season, while fresh weight of vegetative parts was no significant in the second one. The relative decreases of mean values fresh and dry weight of vegetative parts were 8.91 and $10.16 \%$ in the first season and 6.62 and $11.62 \%$ in the second one for water salinity of $5000 \mathrm{ppm}$, respectively compared with control. On the other hand the relative decreases of mean values were 19.47 and $17.35 \%$ in first season and 19.71 and $21.44 \%$ in the second one for water salinity of 8000 ppm, respectively compared with control. Also, the relative decreases mean values of fresh and dry weight of vegetative parts were 29.72 and $29.28 \%$ in the first season and 31.83 and $26.87 \%$ in the second one for water salinity of $12000 \mathrm{ppm}$, respectively compared with control. 
Effect of organic amendments and saline water levels on photosynthesis (mg/g f.w.) in leaves and proline

Data presented in Table (6) show that the increment in chlorophyll ( $a$ and $b$ ) and carotenoids contents in the leaves of Conocarpus erectus plants was significant with decreasing of salt concentration in irrigation water. The plants treated with organic manures (chicken manure and cattle manure combined with bio-fertilizers) showed that the effect on chlorophyll $a$ and $b$ and carotenoids contents in the leaves of Conocarpus erectus plants was greater than without organic manures. Also, the effect of interaction between salinity of water and organic manures on chlorophyll $a$ and $b$ and carotenoids contents in the leaves of
Conocarpus erectus plants was significant in both seasons. The relative decrease of mean values chlorophyll ( $\mathrm{a}$ and $\mathrm{b}$ ) and carotenoids contents in the leaves of Conocarpus erectus plants were $27.67,13.37$ and $9.76 \%$ in the first season and 27.83, 17.20 and $24.51 \%$ in the second season for salinity water of 5000 ppm; $30.58,1.79$ and $24.39 \%$ in the first season and $30.87,25.48$ and $34.51 \%$ in the second one for salinity water of $8000 \mathrm{ppm}$ and $32.04,7.14,26.83 \%$ in first season and $36.52,33.12$ and $37.25 \%$ in second one for salinity water of $12000 \mathrm{ppm}$, respectively. These results are in agreement with those of Shanan (2015) who indicated that the increasing salinity concentration causes reduction in total chlorophyll content.

Table 6. Effect of organic amendments and saline water levels on phytothynases and proline (mg/g f.w.) in leaves of Conocarpus erectus L. in two seasons.

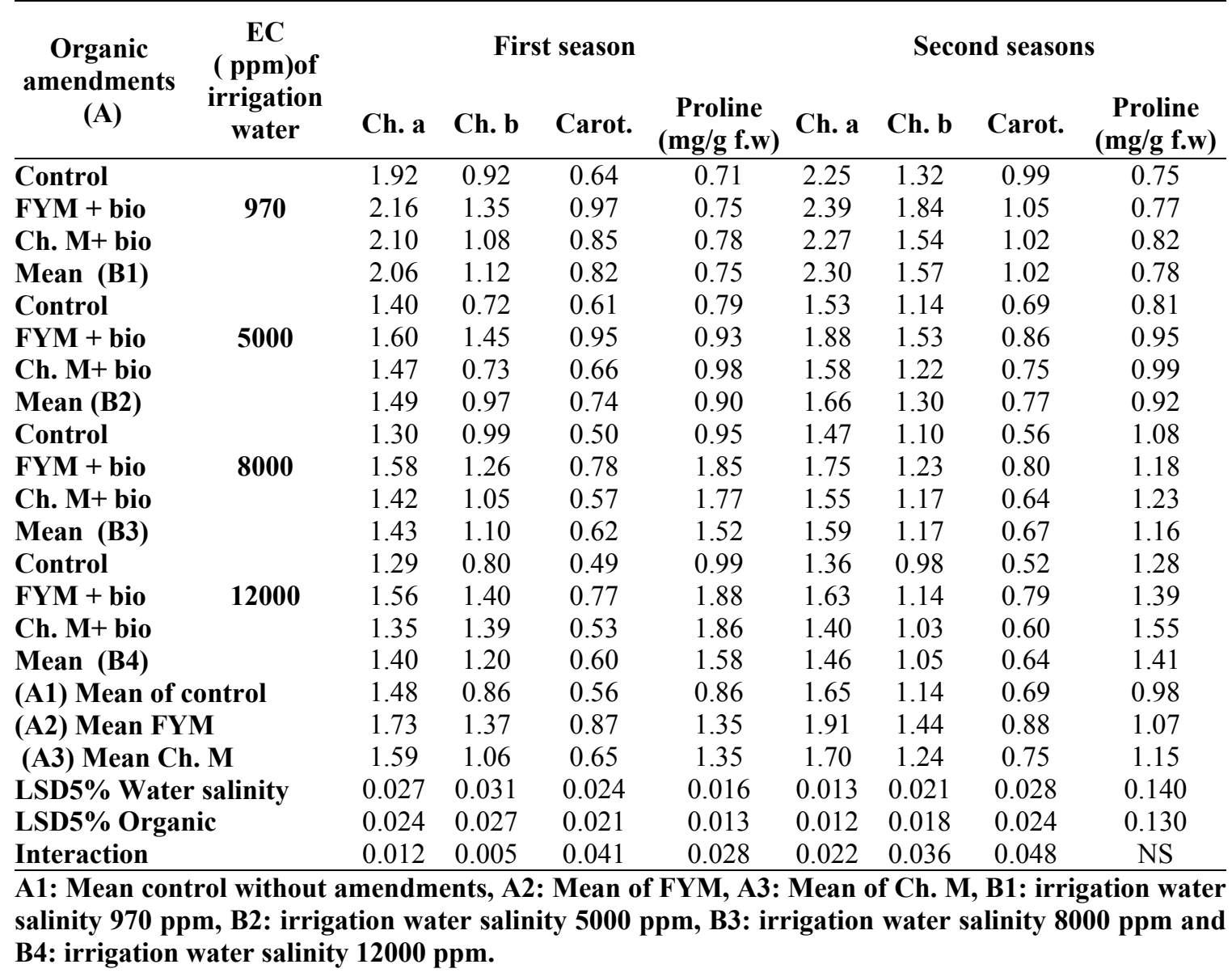


The highest values of chlorophyll (a and b) and carotenoids contents in the leaves of Conocarpus erectus plants were found in plants treated with cattle manures combined with bio-fertilizers compared with other treatments. From the results it was observed that the decrease of this chlorophyll ( $a$ and $b$ ) and carotenoids reflected in increasing salinity water levels. This decrease may be due to the inhibitory effect of chloride on the activity of $\mathrm{Fe}$ containing enzymes, cytochrome oxidase which in turn may decrease the rate of chlorophyll biosynthesis process (Hammad et al., 2010). Muhammad et al. (2014) suggested that the stomata become closed under saline stress because turgor pressure decreased which leads to decrease the photosynthesis.

Proline content in the leaves of Conocarpus erectus transplants was increased with increasing water salinity; as these results are presented in Table (6). The effect of organic manures and irrigation water salinity levels on proline content in the leaves of Conocarpus erectus plants was significant in both seasons with increasing irrigation water salinity. The interactions between different salinity levels for irrigation water and organic manures were significant for proline content in the first season, while no significant in the second one. On the other hand, the relative increase of mean values proline content in the leaves of Conocarpus erectus plants was 20.00, 102.67 and $110.67 \%$ in the first season and $17.95,48.72$ and $80.77 \%$ in the second one for plants treated with irrigation water levels of 5000,8000 and $12000 \mathrm{ppm}$ with or without organic manures compared with control. Increasing proline in plant is considered as indicator for some mechanism to resist the salinity stress (Jampeetong and Brix, 2009). The increase level of proline content enables the plants to maintain osmotic balance when growing under salinity and acts as a major reservoir of energy and nitrogen for utilization by plants subjected to salinity stress (Shanan, 2015).
Effect of irrigation water salinity and organic amendments on $\mathrm{N}, \mathrm{P}, \mathrm{K}, \mathrm{Na}$ and Cl for Conocarpus erectus plants

The presented data in Table (7) show that the $\mathrm{N}, \mathrm{P}, \mathrm{K}, \mathrm{Na}^{+}$and $\mathrm{Cl}^{-}$concentrations $(\%)$ in the leaves of Conocarpus erectus plants of two seasons were decreased with increasing irrigation water salinity levels. The effect of saline water levels and organic manures on $\mathrm{N}, \mathrm{P}, \mathrm{Na}^{+}$and $\mathrm{Cl}^{-}$concentrations in the leaves were significant in the first season while the $\mathrm{N}$ and $\mathrm{Na}^{+}$were non significant in the second one. The interaction effects between different levels salinity irrigation water and added two organic manures on $\mathrm{N}, \mathrm{P}, \mathrm{K}, \mathrm{Na}^{+}$and $\mathrm{Cl}^{-}$were significant as increased with decreasing irrigation water salinity and used organic manures in both seasons, while the $\mathrm{N}$ concentration in the leaves was non significant in the second one.

The corresponding relative decreases of mean values of $\mathrm{N}, \mathrm{P}, \mathrm{K}, \mathrm{Na}^{+}$and $\mathrm{Cl}^{-}$ concentrations the in the leaves of Conocarpus erectus transplants were 8.22, $9.52,5.29,0.76$ and $74.65 \%$ in the first season and $3.62,8.70,4.58,2.76$ and $9.88 \%$ in the second one for irrigation water level salinity of $5 \mathrm{dSm}^{-1}$; 8.68, 14.29, 7.05,2.27 and 82.71 in the first season and 4.98, 15.22, 5.83, 6.90 and $45.45 \%$ in the second one for irrigation water level salinity of $8000 \mathrm{ppm}$ and 9.13, 40.48, 17.18, 9.85 and 109.95 in the first season and 7.24, 30.43, 12.08, 8.97 and $60.87 \%$ in the second one for irrigation water salinity of $12000 \mathrm{ppm}$ respectively, compared with control. Salinity of irrigation water levels may cause nutrient decrease or imbalance, due to the competition of $\mathrm{Na}$ and $\mathrm{Cl}$ with nutrients such as K and N. Abd El-Wahab (2006) found that the increased $\mathrm{NaCl}$ concentration has been reported to induce increases in $\mathrm{Na}$ and $\mathrm{Cl}$ as well as decreases in $\mathrm{N}, \mathrm{P}$ and $\mathrm{K}$ in fennel plants. Abd El-Kader et al. (2006) indicated that the $\mathrm{N}, \mathrm{P}$ and $\mathrm{K}$ concentration in the leaves were decreased with increasing salinity stress. The decrease in $\mathrm{P}$ and $\mathrm{K}$ could be interpreted by the effect of the increased level of $\mathrm{Na}$ whereas the effect of $\mathrm{Cl}$ on $\mathrm{N}$ uptake should be considered. 
Table 7. Effect of organic amendments and saline water levels on macronutrients concentration in leaves of Conocarpus erectus $L$. transplants in two seasons.

\begin{tabular}{|c|c|c|c|c|c|c|c|c|c|c|c|}
\hline \multirow{2}{*}{$\begin{array}{c}\text { Organic } \\
\text { amendments } \\
\text { (A) }\end{array}$} & \multirow{2}{*}{$\begin{array}{c}\text { EC } \\
\text { ( ppm) } \\
\text { of irrigation } \\
\text { water } \\
\text { (B) }\end{array}$} & \multicolumn{5}{|c|}{ First season } & \multicolumn{5}{|c|}{ Second season } \\
\hline & & $\mathbf{N}(\%)$ & P (\%) & K (\%) & $\mathrm{Na}(\%)$ & $\mathrm{Cl}(\%)$ & $\mathbf{N}(\%)$ & P (\%) & K (\%) & $\mathrm{Na}(\%)$ & $\mathrm{Cl}(\%)$ \\
\hline Control & \multirow{3}{*}{970} & 1.97 & 0.40 & 2.10 & 1.30 & 23.19 & 1.99 & 0.48 & 2.32 & 1.43 & 28.18 \\
\hline FYM + bio & & 2.34 & 0.44 & 2.41 & 1.35 & 26.25 & 2.36 & 0.46 & 2.52 & 1.51 & 26.16 \\
\hline Ch. $\mathbf{M}+$ bio & & 2.27 & 0.42 & 2.30 & 1.32 & 25.35 & 2.29 & 0.44 & 2.35 & 1.40 & 23.10 \\
\hline Mean (B1) & \multirow{5}{*}{5000} & 2.19 & 0.42 & 2.27 & 1.32 & 24.93 & 2.21 & 0.46 & 2.40 & 1.45 & 25.81 \\
\hline Control & & 1.82 & 0.34 & 2.05 & 1.38 & 27.16 & 1.95 & 0.42 & 2.25 & 1.46 & 31.55 \\
\hline FYM + bio & & 2.13 & 0.41 & 2.21 & 1.32 & 53.35 & 2.28 & 0.44 & 2.34 & 1.53 & 29.14 \\
\hline Ch. M+ bio & & 2.08 & 0.38 & 2.19 & 1.28 & 50.11 & 2.17 & 0.41 & 2.28 & 1.49 & 24.39 \\
\hline Mean (B2) & & 2.01 & 0.38 & 2.15 & 1.33 & 43.54 & 2.13 & 0.42 & 2.29 & 1.49 & 28.36 \\
\hline Control & \multirow{3}{*}{8000} & 1.80 & 0.33 & 2.01 & 1.42 & 31.20 & 1.92 & 0.38 & 2.21 & 1.52 & 42.11 \\
\hline FYM + bio & & 2.16 & 0.39 & 2.18 & 1.34 & 55.23 & 2.24 & 0.42 & 2.30 & 1.58 & 37.52 \\
\hline Ch. M+ bio & & 2.05 & 0.36 & 2.14 & 1.30 & 50.22 & 2.13 & 0.37 & 2.27 & 1.54 & 33.00 \\
\hline Mean (B3) & \multirow{4}{*}{12000} & 2.00 & 0.36 & 2.11 & 1.35 & 45.55 & 2.10 & 0.39 & 2.26 & 1.55 & 37.54 \\
\hline Control & & 1.78 & 0.29 & 1.85 & 1.49 & 45.98 & 1.88 & 0.35 & 2.18 & 1.55 & 44.51 \\
\hline FYM + bio & & 2.13 & 0.25 & 1.91 & 1.45 & 57. & 2 & 0.33 & 2.10 & 1.62 & 41.96 \\
\hline Ch. M+ bio & & 2.05 & 0.21 & 1.88 & 1.42 & 53.78 & 2.09 & 0.29 & 2.06 & 1.58 & 38.10 \\
\hline \multirow{2}{*}{\multicolumn{2}{|c|}{$\begin{array}{l}\text { Mean (B4) } \\
\text { (A1) Mean of control }\end{array}$}} & 1.99 & 0.25 & 1.88 & 1.45 & 52.34 & 2.05 & 0.32 & 2.11 & 1.58 & 41.52 \\
\hline & & 1.84 & 0.34 & 2.00 & 1.40 & 31.88 & 1.94 & 0.41 & 2.24 & 1.49 & 36.59 \\
\hline \multicolumn{2}{|c|}{ (A2) Mean FYM } & 2.19 & 0.37 & 2.18 & 1.37 & 48.02 & 2.27 & 0.41 & 2.32 & 1.56 & 33.70 \\
\hline \multicolumn{2}{|c|}{ (A3) Mean Ch. M } & 2.11 & 0.34 & 2.13 & 1.33 & 44.87 & 2.17 & 0.38 & 2.24 & 1.50 & 29.65 \\
\hline \multicolumn{2}{|c|}{ LSD5\% Water salinity } & 0.027 & 0.024 & ns & 0.030 & 3.001 & NS & 0.012 & 0.030 & NS & 1.138 \\
\hline \multicolumn{2}{|c|}{ LSD5\% Organic } & 0.024 & 0.021 & 0.097 & 0.025 & 2.60 & NS & 0.011 & 0.026 & 0.025 & 0.985 \\
\hline \multicolumn{2}{|l|}{ Interaction } & 0.047 & 0.042 & 0.168 & 0.052 & 4.50 & NS & 0.020 & 0.044 & 0.043 & 1.96 \\
\hline
\end{tabular}

A1: Mean control without amendments, A2: Mean of FYM, A3: Mean of Ch. M, B1: irrigation water salinity $970 \mathrm{ppm}$, B2: irrigation water salinity $5000 \mathrm{ppm}$, B3: irrigation water salinity $8000 \mathrm{ppm}$ and B4: irrigation water salinity $12000 \mathrm{ppm}$.

\section{CONCLUSION}

The results of the present study indicated that the possibility using the irrigation water salinity levels of 5000 and $8000 \mathrm{ppm}$ and cattle manure combined with bio-fertilizer led to slight increase for all growth parameters of Conocarpus erectus transplants. The used of irrigation water salinity led to increase $\mathrm{Na}, \mathrm{Cl}$ and proline contents in the leaves. We can conclude that Conocarpus erectus L. transplants tolerate salinity up to $5000 \mathrm{ppm}$ for irrigation water and organic manures.

\section{REFERENCES}

Abd El-Aziz, N.G.; Mazher, A.A.M. and Mahgoub, H. (2011). Influence of using organic fertilizer on vegetative growth, flowering and chemical constituents of
Matthiola incana plant grown under saline water irrigation. J. World of Agric. Sci., 7(1):47-54.

Abd El-Kader, A.A.; Mohamedin, A.A.M. and Ahmed, M.K.A. (2006). Growth and yield of sunflower as affected by different salt affected soils. Inter. J. of Agric. and Biology, 8(5):583-578.

Abd El-Wahab, M.A. (2006). The efficiency of using saline and fresh water irrigation as alternating methods of irrigation on the productivity of Foeniculum vulgare Mill subsp. vulgare var. vulgare under North Sinai conditions. Res. J. Agric. Biol. Sci., 2(6):571-577.

Bates, L.S.; Waldren, R.P. and Teare, I.D. (1973). Rapid determination of free 
proline under water stress studies. Plant and Soil, 39:205-207

Branzini, A.; Zubillaga, M.S. and Zubillaga, M.M. (2009). Microbial response to the application of amendments in a contaminated soil with trace elements. Am. J. Environ. Sci., 5(1):94-98.

Cleveland, C.C. and Townsend, A.R. (2006). Nutrient additions to a tropical rain forest drive substantial soil carbon dioxide losses to the atmosphere. Proceedings of the National Academy of Sciences, 103:10316-10321.

Cottenie, A.; Verloo, M.; Kiekens, L.; Velghe, G. and Camerlynck, R. (1982). Chemical Analysis of Plants and Soils. Laboratory of Analytical and Agrochemistry, State Univ., Ghent,Belgium.

Duncan, J. (2005). Composting Chicken Manure. WSU Cooperative Extension, King County Master Gardener and Cooperative Extension Livestock Advisor.

EL-Kady, A.F.Y. and Borham, T. (2013). Hydrogel amendment effects on the performance of buttonwood (Conocarpus erectus L.) transplants growth under saline irrigation water. J. Applied Sci. Res., 9(10):6557-6566.

El-Mahrouk, M.E., El-Nady, M.F. and Hegazi, M.A. (2010). Effect of diluted seawater irrigation and exogenous proline treatments on growth, chemical composition and anatomical characteristics of Conocarpus erectus L. J. Agric. Res., Kafer El-Sheikh Univ., 36:420-446.

Hameed, M.; Ashraf, M.; Ahmad, M.S.A. and Naz, N. (2010). structural and functional adaptations in plants for salinity tolerance. J. Plant. Adap. Phyton., 1:151-170.

Hammad, S.A.R.; Shaban, Kh.A. and Tantawy, M.F. (2010). Studies of salinity tolerance to two peanut cultivars in relation to growth, leaf water content, some chemical aspects and yield. J. of Applied Sci. Res., 6(10):1517-1526.

Hasan, P.H. (2010). Examining the effect of saline water on quantitative and qualitative characteristics of seeds in medicinal herb. Agriculture and Agronomy Journal, 6(2):13-20.

Jampeetong, A. and Brix, H. (2009). Nitrogen nutrition of Salvinia natans: effects of inorganic nitrogen form on growth, morphology, nitrate reductase activity and uptake kinetics of ammonium and nitrate. Aquat. Bot., 90:67-73.

Kennedy, I.R.; Choudhury, A.T.M.A. and Kecskes, M.L. (2004). Nonsymbiotic bacterial diazotrophs in crop-farming systems: can their potential for plant growth promotion be better exploited? Soil Biology and Biochemistry, 36(8):1229-1244.

Khaled, A. Sh.; Mona, G.A. and Seham, M.E. (2011). Evaluation of organic farm and compost combined with urea fertilizers on fertility and maize productivity in newly reclaimed. Res. J. of Agric. and Biol. Sci., 7(5):388-397.

Kim, H.T. (1996). Soil Sampling, Preparation and Analysis. Marcel Dekker Inc., New York, 391 pp.

Loutfy, I.E. and Ibrahim, M.A. (2005). Interactive effects of low water supply and high salt concentration on the growth and dry matter partitioning of Conocarpus erectus transplants. Saudi J. of Biol. Sci., 12(2):147-157.

Maksimovic, I. and Ilin, Z. (2012). Effects of Salinity on Vegetable Growth and Nutrients Uptake, Irrigation Systems and Practices in Challenging Environments, T.S. Lee (Ed.).

Mohammad, J.; Abdolhpour, M. and Amineh, H. (2015). Effect of saline water on morphological characteristics of Conocarpus plant for using in green space warm and arid cities. Biolo. Foeum-An Inter. J., 7(2):31-34. 


\section{Hanan E. Ibrahem}

Muhammad, A.; Muhammad, S.; Balal, Y.; Muhammad, A.; Yousaf, A.; Athar, A. and Daniyal, S. (2014). Growth and ionic composition of buttonwood (Conocarpus erectus L.) in response to soil salinity and water stress. Advances in Life Sci. and Tech., 19:42-52.

Muhammad, D., R.A. Khattak, (2009). Growth and nutrient concentration of maize in pressmud treated salinesodic soils. Soil Environ., 28:145-155.

Oagile, D. and Namasiku, M. (2010). Chicken manure enhanced soil fertility and productivity: Effect of application rates. J. of Soil. Sci and Environ. Management, 1(3):46-54.

Page, A.L.; Miller, R.H. and Keeney, D.R. (1982). Methods of Soil Analysis. II. Chemical and Microbiological Properties. $2^{\text {nd }}$ Ed. Madison, Wisconsin, U.S.A.

Ryan, J.; Garabet, S.; Harmsen, K. and Rashid, A. (1996). A Soil and Plant Analysis. Manual Adapted for the West Asia and North Africa Region. ICARDA, Aleppo, Syria, 140.
Sarwar, G.; Schmeisky, H.; Tahir, A.; Iftikhar, Y. and Sabah, N. (2010). Application of green compost for improvement in soil chemical properties and fertility status. Journal of Animal \& Plant Sciences, 20(4):258-260.

Shanan, N. (2015). Alleviation of salt stress by stimulative compound in Matthiola incana L. plants. Inter. J. of Advanced Res., 3(9):335-375.

Snedecor, G.W. and Cochran, W.G. (1990). Statistical Methods. $8^{\text {th }}$ Ed., Iowa State Univ. Press, Ames, Iowa, USA.

Venkatashwarlu, B. (2008). Role of biofertilizers inorganic farming: Organic farming in rain fed agriculture: Central Institute for Dry Land Agriculture, Hyderabad, 85-95.

Witham, F.H.; Blaydes, D.F. and Devin, P.M. (1971). Experiments in Plant Physiology. Van Nosland Reihold. Co. New York, 55-58.

\footnotetext{
تاثير مستويات ملوحة مياه الرى والسماد العضوى المتحد مع السماد الحيوى على انتاجية شجيرات الكونوكاربس$$
\text { حنان عز الدين ابراهيم }
$$$$
\text { قسم بحوث الزينة وتنسيق الحدائق، معهد بحوث البساتين، مركز البحوث الزر اعية، الجيزة، مصر. }
$$

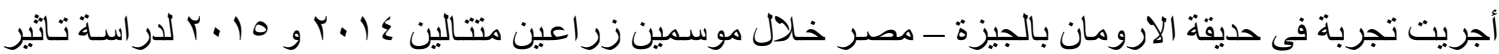

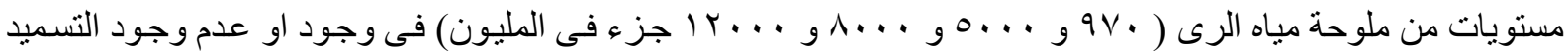

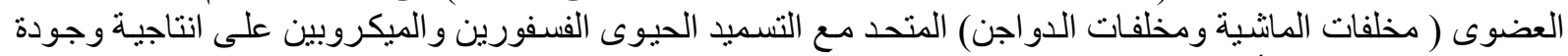

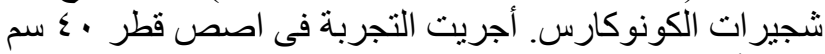

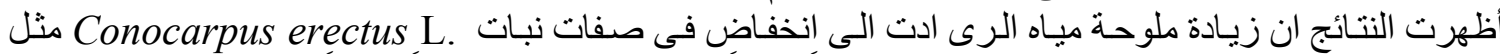

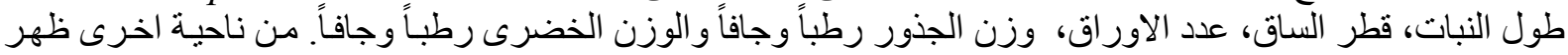

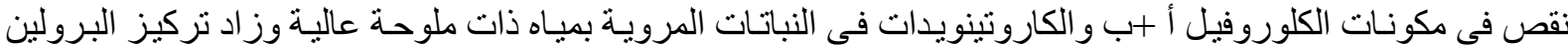

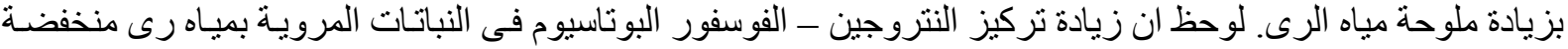

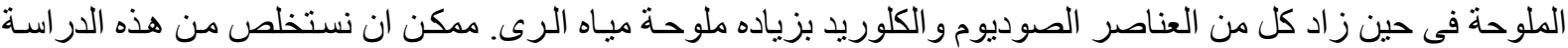

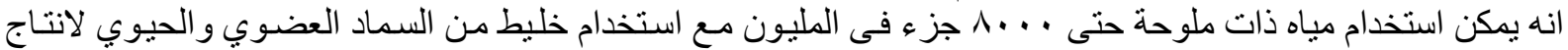

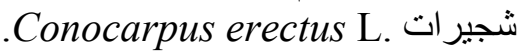

